\title{
The Historical Past and the Dramatic Present
}

Toward a Pragmatic Clarification of Historical Consciousness

\section{Vincent Colapietro}

\section{(2) OpenEdition \\ Journals}

Electronic version

URL: http://journals.openedition.org/ejpap/627

DOI: $10.4000 /$ ejpap.627

ISSN: 2036-4091

Publisher

Associazione Pragma

\section{Electronic reference}

Vincent Colapietro, «The Historical Past and the Dramatic Present », European Journal of Pragmatism and American Philosophy [Online], VIII-2 | 2016, Online since 16 January 2017, connection on 20 April 2019. URL : http://journals.openedition.org/ejpap/627 ; DOI : 10.4000/ejpap.627

This text was automatically generated on 20 April 2019.

\section{(c) $($ ) $\odot$ (8)}

Author retains copyright and grants the European Journal of Pragmatism and American Philosophy right of first publication with the work simultaneously licensed under a Creative Commons AttributionNonCommercial-NoDerivatives 4.0 International License. 


\title{
The Historical Past and the Dramatic Present
}

\author{
Toward a Pragmatic Clarification of Historical Consciousness
}

\author{
Vincent Colapietro
}

"The stone the builders rejected has become the head of the corner[stone]."

Max H. Fisch

\section{Introduction: An Exemplary Engagement with Intellectual History}

1 The aim of this paper is to show the depth to which C. S. Peirce, as a philosopher, was guided by his engagement with history and to clarify pragmatically what history means in this connection. This engagement prompted him to do original historical research and also reflect on historiographical practices. This work was truly exemplary. While this topic has hardly been ignored, ${ }^{2}$ it calls for much fuller exploration than it has yet received. This is especially true since Peirce's understanding of history itself calls for more careful consideration, far more probing than it has yet received. As necessary as it is to explore the place of history in his classification of the sciences, this is not sufficient. This essay is designed to complement studies focusing on the conception of history to be obtained from an exploration of that scheme.

2 Its main focus is on a pivotal but implicit distinction, the distinction between historical knowledge and consciousness. Peirce came very early in his life to see the attainment of historical knowledge and, more generally, of knowledge in all fields of scientific inquiry in the context of reflexive consciousness: his thought encompassed an awareness of the historicity of these pursuits and, moreover, the most salient implications of their essentially historical character. This distinction is however related to another crucial one, that between an abstract definition and a pragmatic clarification of the historical past. Here as elsewhere Peirce's pragmatism does not compromise his realism: when abstractly defined, the past stands in irreducible otherness to the present, but when pragmatically 
clarified, it is what experimental inquirers might more or less reliably reconstruct on the basis of such historical evidence as monuments, documents, and other traces of the past. Pragmatically defined, the historical past is, in its most rudimentary sense, the discoverable past (both that something had taken place and what had assumed a determinate, discoverable form in the flux of history). As such, it is to some extent intelligible (e.g., whatever its significance, Stonehenge is a human artifact, not a geological formation, and in principle its functions or significance are discoverable). In its more refined forms, however, the pragmatic clarification of the historical past pushes beyond historical knowledge and drives toward historical consciousness: experimental inquirers thereby acquire a more or less explicit awareness of the historical drama in which they are implicated agents. Such agential awareness is what I mean by historical consciousness.

3 Peirce's understanding of history is indeed subtle, nuanced, and in no small measure elusive. It is bound up with virtually all of his most important doctrines, most notably, his realism, pragmatism, commonsensism, and synechism. In this paper, however, I cannot even approximate doing justice to all of these linkages. For my purpose, Peirce's realism and pragmatism are at the focus of our exploration, but consideration of his synechism (or doctrine of continuity), however brief, is necessary. The past, as past, is continuous with the present. What is no longer actual in the strongest possible sense (haecceity) is nonetheless real and, moreover, even actual in an attenuated sense. In his lexicon, reality is not synonymous with actuality (or haecceity). The real is what would disclose itself in the fullness of time, whereas the actual is what exerts itself here and now (Boler 1963: 51, 58; Short 2007: 86-7, 50, 70-8). ${ }^{3}$ In particular, the actuality of the past is, for Peirce at least, just that - an instance of actuality. But the actuality of the past stands in marked contrast to the actuality (or haecceity) of the present. Finally, our knowledge of the past can contribute to a "historical sense" in the living present. Because this is an agential sense, one acquired and developed by agents caught up in the flux of historicity, it is ineluctably a dramatic sense. The perspective of agents, implicated in evolved and evolving practices, the outcomes of which hang in the balance, becomes in part that of a self-conscious participant in an unfolding drama (cf. CP 7.572). This sense is nonetheless tied but not reducible to such knowledge. Hence it is necessary to distinguish between historical knowledge and historical consciousness (or imagination). There is, on the one hand, the knowledge obtained by historical actors and, on the other, the awareness on the part of such actors of the nature of their undertaking. These are distinct yet ultimately inseparable.

The principal task of this paper is, hence, to draw the requisite distinctions for understanding the most important features of Peirce's distinctive vision of human history, above all, the one just formulated. Only by drawing these various distinctions can we begin to comprehend the depth and character of this vision. For this purpose, none is (to repeat) more important than that between historical knowledge and consciousness. No denigration of the hard-won knowledge of the past is implied here. Just as imagination (at least the strictly scientific imagination) needs to be tempered and tutored by experience, so too experience needs to be continually recontextualized and illuminated by imagination. Let us now consider in greater detail the distinction around which I allege everything turns. 


\section{The Craft of Historical Inquiry and the Cultivation of Historical Consciousness}

5 Peirce's engagement with the writing of history began in his youth. At twelve years of age, he undertook the study of chemistry and, several years later, the task of writing a history of that science (Fisch 1986: 403; also his Introduction to $W 1$ : xxvii-xix). This trajectory turned out to be a definitive tendency in his intellectual life (Eisele 1979: esp. Ch. 3, 7, and 10; Fisch 1986: Ch. 20, esp. 385-9). ${ }^{4}$ He very early forged the conviction that nothing is fully intelligible apart from the history in which the story of how it arose and evolved is detailed. He was not fixated on origins, but focused on the entire course of typically ongoing developments (cf. Peirce 1966: 403). This lifelong conviction encompassed a disciplined desire not only to acquire accurate knowledge of past deeds, but also to attain a nuanced consciousness of the historicity of our diverse undertakings. The accuracy of this knowledge was, in the end, arguably slightly less important than the liveliness of this consciousness. But this does not carry any disparagement of the demanding task of obtaining reliable knowledge of past events. It only means that the imaginative venture of deepening historical consciousness is of overarching importance. ${ }^{5}$

Shortly after being led by his study of chemistry to assembling a history of that science, Peirce by accident caught a glimpse of the science that would enthrall him for the entirety of his life. To Victoria Lady Welby Peirce late in his life wrote:

Know that from the day when at the age of twelve or thirteen I took up, in my elder brother's room a copy of [Richard] Whately's Logic, and asked him what logic was, and getting some simple answer, flung myself on the floor and buried myself in it, it has never been in my power to study anything [...] except as a study of semeiotic [...

] (Peirce 1966: 408)

7 In 1861, he wrote as the last entry of his class-book: "No longer wondered what I would do in life but defined my object." That object was logic, eventually re-envisioned as a general theory of signs, inclusive of a normative account of inquiry (Ransdell 2000: 342). Even when he was investigating topics by which he was inherently fascinated, he was also studying them for sake of deepening his understanding of logic, that is, the working of signs.

As illuminating as this revelation is, it is likely to be misleading. For even before this, another tendency, indeed a complementary one, had taken root: from very early in his intellectual development, it was never in his power to study anything, including semeiotic (of the theory of signs), except historically. His propensity to study whatever captivated his interest in light of semeiotic was from the beginning conjoined to his propensity to consider everything in light of history (Colapietro 2004).

His first public address, given November 12, 1863, was entitled "The Place of Our Age in the History of Civilization" (Peirce 1966: Ch. 1). At the height of his maturity, he published an essay appearing in the New York Evening Post (January 12,1901) as "Review of the Nineteenth Century" and in the Annual Report of the Smithsonian Institution (Washington, D. C., 1901) as "The Century's Great Men in Science." He concludes this piece by suggesting, "To an earlier age knowledge was power, merely that and nothing more." In his own time, however, the pursuit of knowledge had become not only a way of life ${ }^{6}$ but also "the summum bonum." "Emancipation from the bonds of self, of one's own prepossessions, importunately sought at the hands of the rational power before which all 
must ultimately bow - this is," Peirce contends, "the characteristic that distinguishes all the great figures of the nineteenth-century century from those of former periods" (Peirce 1966: 274).

10 His thoroughgoing identification with the leading figures in this historical development, pragmatically, means a dramatic sense of his personal participation in an ongoing dialogue, that is, a sense of his role in this drama. ${ }^{7}$ In this context, it is appropriate to recall his numerous efforts to draft a finely detailed history of scientific inquiry, stretching back before the ancient Greeks and driving forward to the cutting edge of his historical moment. The fledgling chemist who undertook the task of writing the history of chemistry matured into a philosophical historian who indefatigably researched the historical antecedents to his contemporary world, especially the dramatic transformations due to scientific inquiry (again see Eisele, also Fisch). The lessons to be drawn from the history of science were, as much as anything else, lessons for philosophers (cf. CP 5.364). Peirce was confident that, in time, they would prove to be invaluable in assisting honest philosophical inquirers to re-envision nothing less than the very nature of their undertaking, including that of logic (and logic as semeiotic). ${ }^{8}$

11 Regarding this, he was anything but a spectator. He was self-consciously an agent who took himself to be responsible, in some measure, for the development of a practice. Accordingly, a dramatic sense of his intellectual obligations animated and guided his orientation toward the past and also his involvement in the disputes of his own day, not least of all, the dispute between the progeny of the scholastic realists and the offspring of the Renaissance humanists. ${ }^{9}$ In brief, his understanding of the past fostered a consciousness of his role in a drama. More than anything else, this is what I mean by historical consciousness as distinct from historical knowledge. This is a distinction, not a dichotomy or dualism. Peirce was convinced that the reality of the past was, to some extent, discoverable. He was unquestionably a realist, not a skeptic or what is commonly called a constructivist. But he was also a pragmatist. Whatever reality (including the reality of the past) means must be spelled out in terms of habits of conduct bearing upon the future. Part of the difficulty is giving equal weight to both the realist and pragmatist facets of his thought, another part showing how they are anything but incompatible.

It would be hard to exaggerate the extent to which Peirce was committed to approaching logic, science, and any topic of interest to him from the hard-won perspective of detailed historical knowledge. Such a perspective however fosters what W. B. Gallie calls "historical imagination" (1968: 146). Even more than this perspective flowing from such imagination, it flows into more developed, explicit, and nuanced forms of this singular heuristic capacity. Such imagination is dramatic by virtue of being historical, since it fosters a sense of one's fateful entanglement in an ongoing history.

In one of his most detailed contributions to intellectual history (his extended review of Fraser's critical edition of Berkeley's collected writings), Peirce considers his own time in contrast to Berkeley's: "the minds from whom the spirit of the age emanates have now no interest in the only problems that metaphysics ever pretended to solve" (EP 1: 84) - God, freedom, and immortality. Moreover, the "few who do now care for metaphysics are not of that bold order of mind who delight to hold a position so unsheltered by the prejudices of common sense as that of the good bishop" (EP 1: 84). That is, these few in their metaphysics hew closely to these prejudices. "As a matter of history, however, philosophy [including metaphysics] must always be interesting" (emphasis added), even to antimetaphysical minds. What he goes on to claim is even more pertinent to our purpose: the 
history of philosophy "is the best representative of the mental development of each age. It is so even of ours, if we think what really is our philosophy." But this facet of development needs to be considered in conjunction with other ones. "Metaphysical history is," Peirce insists, "one of the chief branches of history, and ought to be expounded side by side with the history of society, of government, and of war; for in its relations with these we trace the significance of events for the human mind" (EP 1: 84).

Unlike most philosophers, however, Peirce's understanding of history is in accord with the practice of historians, at least, those committed to testing their hypotheses about the past by means of the traces of that past (e.g., monuments, documents, and other empirical evidence). Professional philosophers seem to have difficulty expounding intellectual history and, more narrowly, philosophical history in a manner that would be recognizable to the historian as history. Part of this is that too little care is given to evidence, part also that too little attention is paid to what historians and those other than philosophers have written about the topics under consideration. In these respects, Peirce distinguished himself from such philosophers. In reference to history no less than to, say, physics, chemistry, or biology, the outward clash of relevant experience possessed a critical relevance (Viola 2015). What William James wrote in a letter to his brother Henry in reference to psychology was, in Peirce's judgment, true of any form of inquiry: "I have to forge every sentence in the teeth of irreducible and stubborn facts." Of course, these facts are not data. They must themselves be painstakingly established. They must also be imaginatively envisioned. The inquirer "can stare stupidly at phenomena; but in the absence of imagination they will not connect themselves in any rational [or intelligible] manner" ( $C P$ 1.46). To look at phenomena intelligently means, for Peirce, looking at them imaginatively or "fancifully." 10 This is as true of the historian as any other inquirer. What makes Peirce's lifelong engagement in intellectual history so exemplary is that, unlike most philosophers, he possessed an interior sense of the demanding craft of historical inquiry.

15 To study anything historically, in Peirce's judgment, did not mean simply or even primarily tracing that thing to its origin, but detailing the still unfolding drama of a continually renewed endeavor (e.g., the endeavor wherein a generation just coming into its own renews the undertaking of preceding generations, such as we witness in the case of sciences such as physics, chemistry, or indeed history itself). However it might be with their counterparts in physics or chemistry, virtually all contemporary historians possess a working sense of the historical development of their intellectual vocation. Chemists without much knowledge of the history of their own science are hardly exceptional, whereas historians ignorant of Herodotus, Thucydides, and other practitioners of their craft would be.

16 In any event, Peirce was in his time rather exceptional in his devotion to cultivating, precisely as a conscientious participant in experimental inquiry, a historical consciousness of his passionate engagement in various scientific fields (Esposito 1984; Viola 2015). Such consciousness is not the same as knowledge of the history of these fields, though it is unattainable apart from such knowledge. In the sense intended here, such consciousness designates, above all else, a sense of the past in its bearing on the present. Insofar as this is different, it also designates a sense of the present as derived from the past. Moreover, it includes the recognition that this sense itself is through and through historical: it does not pretend to imply a perspective above or beyond history. ${ }^{11}$ 

a twofold sense. Historical consciousness is, for an agent caught up in an endeavor such as parenting, teaching, or inquiring, crucial or indispensable. It is, moreover, critical in the sense that history provides both invaluable resources for attaining a critical distance from present preoccupations and securing possible criteria for judging contemporary performances. In this sense, history in the service of life (even simply the life of the craftsperson) is critical in the sense identified by Nietzsche. In brief, one of the uses of history is to foster a critical sensibility. Though it does not necessarily do so, historical consciousness can function as critical consciousness (cf. Trilling 2008: 196): a sense of the past in its bearing on the present can enliven and emancipate those devoted to making something significant and memorable of the present. In its ability to accomplish this, the historical sense "is to be understood as the critical sense, as the sense which life uses to test itself" (Trilling 2008: 196). It is the sense which life also uses to transform and transcend itself, that is, modify its inherited or habituated forms of striving. In other words, history here is pressed into the service of self-overcoming.

The craft of the responsible historian is one thing, the cultivation of historical consciousness quite another, even if the cultivation of such consciousness is hardly possible apart from what only can be accomplished by the painstaking discipline of detailed memorialization. There is, in the foreground of Peirce's preoccupation with history, critical attention to the distinctive methodology of historical inquiry (i.e., to how historians as inquirers into the past can most responsibly and effectively carry out their task). He includes history in his classification of the sciences and its locus in this scheme provides insights into what he takes history to be (see, e.g., Peirce CP 1. 272; also Miller 1971 and 1972; and Esposito 1983: esp. 156-7). But history is more than a narrowly delimited field of experimental inquiry. ${ }^{12}$ It is also an indefinitely expansive consciousness of any human endeavor, attainable by participants in the endeavor. That is, there is, in the background of Peirce's fascination with history, the deliberate cultivation of historical consciousness, an awareness of one's role in the drama in which one is so fatefully entangled (see, e.g., CP 7.572; and Colapietro 2016). From his perspective, agents ought to cultivate such consciousness, principally for the sake of acquiring a fuller, deeper sense of their own agency and, indeed, also a candid, contrite sense of the limits of that agency.

\section{First Steps toward a Pragmatic Clarification of the Historical Past}

At this juncture, however, I want to highlight another distinction, indeed, one of the most basic distinctions in all of Peirce's philosophical writings, one drawn at least as early as 1878 and deployed with varying degrees of consistency ever afterwards. It is at the center of Peirce's effort to close or, at least, reduce the distance between our theoretical understanding of logical procedure (logica docens) and the working logic (logica utens) of the most successful inquirers. It is attempt to make explicit, in the form of a maxim, what inquirers tend to do in their efforts to render their efforts experimental. That is, the logica utens of the most successful sciences ought to inform our logica docens (part of the task of the latter being to make more explicit than we have yet done the former). If our logica docens is to move toward catching up with our logica utens, we must move beyond abstract definitions and insist upon pragmatic clarifications. As it turns out, however, 
pragmatic clarification in its most rudimentary form needs itself to be supplemented by such clarification in ever more refined, reflexive forms. In particular, the dispositional properties of inquiring subjects need themselves to be made explicit, indeed, the foci of criticism, not just the dispositional properties of investigated objects. To take a simple example, "hardness" is pragmatically clarified when it is conceived as how a substance would behave in reaction to certain operations (e.g., being scratched by a diamond). This is however only one half of the story, for how experimental inquirers, as deliberate agents, ought to comport themselves in the context of inquiry is also critical. The dispositions of experimental investigators call for critical attention as much as those of the experimental objects and events being investigated. These dispositions range from very simple operations (e.g., submerging litmus paper in a liquid and observing specifically how the paper is disposed to react to such submergence) to formally reflexive habits (e.g., the disposition to attend with the most painstaking care the manner in which an experiment was conducted and, beyond this, the disposition to imagine one's specific line of research as a contribution to a vast network of analogous endeavors).

In Peirce's judgment, traditional logic had not caught up to the best practices of the most successful investigations. The degree of clarity demanded in such investigations was higher than those formally acknowledged by logicians (those who ought to provide a normative account of objective inquiry). The famous pair of "claire et distincte" translated into practice to mean tacitly familiar and formally defined. Even apart from the ability to define the word triangle, one might know how to use this word in countless contexts and such ability embodies a rudimentary level of conceptual clarity (it shows that one has grasped, in however indistinct a manner, what the term means by being able, for example, to grasp what others mean when they use it). Abstract definition provides a higher grade of conceptual clarity. And traditional logic has rested content with the attainment provided by such formal distinctness.

In Peirce's judgment, however, tacit familiarity and abstract definition need to be supplemented by pragmatic clarification. The practice of inquiry suggests as much, as does the attempt to draw out some of the implications from Alexander Bain's definition of belief (Fisch 1986: Ch.5). Bain's definition of belief, as that upon which a person is prepared to act (see, e.g., Peirce CP 5.12), is an improvement upon Locke's suggestion, "I have always thought that the actions of men are the best interpreters of their thoughts." For actions might be taken to mean simply that which takes place hic et nunc, rather than that which is expressive of a purpose or indicative of a habit. ${ }^{13}$ The "dumb" smarts of competent agents and the formal definitions of those careful inquirers who desire to draw distinctly the boundaries of what they are investigating are indispensable tools. But the practice of inquirers reveals the need to translate their concepts into habits of action, on both sides - the side of the object being investigated (How is, for example, salt disposed to act when immersed in a liquid such as water?) and that of the agent undertaking the investigation. Only by doing so will we effectively break out of the circle of words and expose our claims to the rough-and-tumble world of experience (cf. Short 2007: 56-9); only then do we adequately learn what in the course of experience counts against our claims and attributions, only then are objects granted their dialogical right to be what their name implies (for only then are they in a position to object). ${ }^{14}$ It is surprising that even some of the most informed and insightful scholars still all too infrequently use this simple and fundamental distinction, one explicitly and indeed repeatedly drawn by Peirce, as an interpretive key to his philosophical writings. This is 
even true in the case of their treatment of such topics as his account of science, definition of semiosis, and stance on realism, though Peirce illustrates the meaning of his maxim (to some degree, the practical import of the pragmatic maxim itself) by recourse to the concept of reality. It must however be acknowledged that Peirce himself is part of the problem, since he not infrequently fails to push his thought on a topic beyond the intermediate level of abstract definition. Consider, for example, the character of so many of his definitions of sign or semiosis. At least on the surface, these appear to be abstract definitions. Though he explicitly warns us to be on our "guard against the deceptions of abstract definitions" (CP 7.362), he trades rather freely in such definitions. So many of his expositors have been themselves deceived by this tendency on Peirce's own part, or so it seems to me. At his best, however, Peirce is at his most pragmatic and, at his most pragmatic, he is committed to translating his thought about any topic whatsoever into habits of action. ${ }^{15}$

We can ascertain the full force of the pivotal distinction between abstract definition and pragmatic clarification only by seeing it as part of a trichotomy (tacit familiarity, formal definition, and pragmatic clarity). What we need to become clear about is the reality of the past, on the one hand, and our more or less reliable knowledge and, beyond this, our dramatic consciousness of that reality, on the other hand. I however resist identifying these two facets of our concern as the ontology and epistemology of history, because questions regarding such knowledge are, in the spirit of Peirce's project, better identified as methodological than as epistemological (Ransdell 2000: 348-50). The point is that the possibility of such knowledge is not in question. Here as much as anywhere else (if not more than most other contexts), we ought not to pretend to doubt in our philosophy what we do not doubt in our hearts (CP 5.265). And we do not - in certain respects, we cannot - practically doubt either the reality of the past or our knowledge of that reality. Indeed, every form of our knowledge is in some manner and measure historical. If we did not possess a more or less reliable sense of what we have done and what has befallen us (above all, what has befallen us as a consequence of how we have comported ourselves (cf. Dewey, MW 10)), we would be precluded from knowing anything at all. The meaning of our words (not least of all, the meaning of the word doubt) must be relatively steadfast if we are to articulate our doubts, if these words are to be meaningful signs rather than semantically empty sounds or squiggles. Hence, the stability of their meanings, however relative and alterable, in effect bears testimony to the reliability of memory. The continuity of unconscious, largely unacknowledged habits is much deeper than that of our conscious, voluntarily conjured memories. Indeed, such memories depend, to a far greater extent than we tend to appreciate, on such habits.

Our beliefs, what we act or go on, are distillations of history, though in the case of innate or instinctual dispositions, they are distillations not of our personal but of our evolutionary history. The doubts indicative of the inadequacy of our beliefs are, in turn, episodes in which history is manifestly "a-making" (CP 6.301). At the most rudimentary level, then, our "knowledge" of the past is unreflectively practical and almost wholly tacit. The vast, vague background upon which our deliberative rationality draws is immeasurably vast and irreducibly vague.

For our purpose, what additionally merits notice is the distinction among three aspects of the past. Confusion will result if we fail to distinguish the past in its indefinite determinability, in its irreducible otherness, and in its fateful continuity. It must seem contradictory to claim, at once, that the past is indefinitely determinable and truly 
irrevocable. But this contradiction is apparent, not real. The past in its actuality - the past in its secondness (I am disposed to say, simply, the past as past) - is irrevocable, whereas the significance of the past is determinable in ways not fixed by the irrevocability of the past. For example, the significance of the outcome of the Civil War in the United States - the defeat of the Confederacy by the Union - did not mean, irrevocably, the defeat of a country in which states' rights were subordinate to federal authority. Indeed, the decades after that war were ones in which the effective authority of the federal government became or simply remained in crucial respects very limited. In the 1950s, President Dwight Eisenhower was, for example, reluctant to send federal troops into southern states to insure compliance with federal law (the desegregation of schools in, for example, Little Rock, Arkansas).

The abstract definition of the reality of the past is one in which the secondness of the past is foregrounded, whereas pragmatic clarifications tend to be ones in which some form of thirdness is rendered prominent. This runs strictly parallel to what Peirce suggested about reality simpliciter. Some might be inclined to argue this makes matters too simple. But there is an advantage of beginning here and introducing greater complexity as fuller attention to the relevant phenomena require or simply invite us to do. Lest the main point is obscured or worse, lost entirely, let me stress the need to string the bow, by bringing one end (that of irrevocability) close enough to the other (that of intelligibility and, hence, of revisability) so that a sufficiently taut fiber can be put in place. It would be hyperbolic to suggest that this task requires Herculean strength! But it does demand arduous or at least careful thought.

27 A sufficiently developed pragmatic conception of the historical past includes both a rudimentary clarification of what this past pragmatically means and a reflexive understanding of the undertaking of the historical inquirer (i.e., the inquirer into what has taken determinate, discoverable form in the flux of history). This either is or is intimately akin to the pivotal distinction between historical knowledge and historical consciousness. What the historical past pragmatically means is what historical inquiry is destined to disclose. But what such inquiry itself most fundamentally means turns out to require the cultivation of a reflexive, agential consciousness of both one's role in such an inquiry and the role of such an endeavor in the unfolding drama of experimental intelligence. Accordingly, a pragmatic clarification of historical consciousness requires nothing less than for experimental inquirers to conceive themselves as deliberative agents and, in turn, for such agents to conceive themselves as historical actors. For this purpose, the deliberate control of conduct in a specific field of endeavor is necessary but not sufficient. If we appreciate the implicit import of Peirce's pragmatist stance, then only a deliberately cultivated consciousness of one's historical role in an unfolding drama - an agential sense of the historical present - offers a sufficiently pragmatic clarification of the historical past.

But this implication seems to work against what Peirce so indefatigably defends. The development of historical consciousness can be made to look at odds with the attainment of historical knowledge. The espousal of the ideal of objectivity can be made to look inconsistent with the actual work of reconstructing the historical past, since such reconstruction is an instance of construction and, as such, seems to imply a form of constructivism. Does not Peirce's thought, in driving toward historical consciousness, undermine its own realistic aspirations, does not its acknowledgment of the historicity of science undercut its commonsensism? Put yet otherwise, is not Peirce ultimately forced 
to abandon his commitment to objectivism in favor of what has been called a transcendentalist perspective? Such questions turn out to be part of the historical record. They have been pressed by one of the most insightful readers of Peirce's entire oeuvre, from the earliest juvenilia to the most mature writings.

\section{Commonsensical Realism, Unconstrained Constructivism, and Peircean Pragmatism}

One of the most erudite and penetrating expositors of Peirce has not only written a critique of Peirce's views regarding history (Esposito 1983, 1984) but also formulated in detail his own subtle position regarding this thorny topic (Esposito 1984). In "Peirce and the Philosophy of History" (1983), Joseph L. Esposito highlights an apparent tension in Peirce's largely implicit philosophy of the historical past. There is, he alleges, a tension between a commonsensical understanding of the past and what he rather unfortunately calls a "transcendental" approach. In Peircean terms, the former stresses the secondness or objectivity of the past, whereas the latter emphasizes thirdness or intelligibility. In The Transcendence of History: Essays on the Evolution of Historical Consciousness (1984), he reiterates (though without reference to Peirce) his critique of "objectivism" or "realism" but also presents his own account of history, one deeply indebted to Hegel but also to Peirce (see especially 1984: 45, 165). It is accordingly surprising that, at least as far as I know, no defender of Peirce has taken up the challenge implicit in this critique. Nor has anyone assessed whether Esposito's appeal to Peirce's insights is justified (Is Peirce truly an ally in articulating the approach to history championed by Esposito in his book?). Hence, I want in this essay, among other tasks, to take up this challenge. My ultimate objective in this section however is positive rather than critical, this goal being to work toward attaining a pragmatic clarification of the historical past. But my proximate goal is to show that Peirce's views regarding this past are more coherent and defensible than Joseph Esposito claims. In fairness, Esposito does not make a strong claim regarding any fundamental incoherence in Peirce's philosophy of history and he even suggests what I take to be the most effective way of dispelling the appearance of such a flaw.

Esposito does however claim to discern a tension in Peirce's treatments of history between an objectivist and a transcendentalist (or constructivist) account. This distinction "corresponds roughly [I would urge, very roughly] to the common-sense distinction between history as that which the historian studies and history as that which the historian produces [or constructs] from his study" (Esposito 1983: 156). Esposito significantly frames the distinction in terms of consciousness. For the objectivist, "without a past to study [without the actuality or reality of temporally superseded events, actions and structures] there would be no historical consciousness." For the constructivist, however, "without historical consciousness there would be no historical past." ${ }^{16}$ Esposito is disposed to ask, "Was Peirce an objectivist or transcendentalist?" In other words, was he a commonsensical realist regarding the historical past or an imaginative constructivist? Some passages imply a commitment to such realism, while others suggest a leaning toward a form of constructivism. As it turns out, we must also ask, Are these the most appropriate or illuminating terms by which to identify this tension? 

surprise Esposito discerns disparate or even conflicting tendencies in Peirce's writings. But he does more than this. He suggests a way of possibly reconciling them. It would thus be very instructive here to recall some of the most important details of Esposito's nuanced interpretation of Peirce's own subtle position. Another name for the objectivist is realist (see Esposito 1984: 86-7), since the advocate of this position insists upon the reality of the past. However much they might rely upon the techniques of literary fiction, the practitioners of responsible historiography do not take themselves to be composing fiction; they are deeply appreciative of the defining characteristics of historical narrative vis-à-vis more freely fictive genres (e.g., purely novelistic narrative). Put more simply, the constraints on the historian are greater than those on a novelist. This does not imply that there are no constraints on a novelist, simply that they are quite different from those on the historian. While historical facts, like all other ones, are forged in the crucible of painstaking inquiry, the processes by which they are forged are in crucial respects different from those of more purely imaginative authors (cf. Esposito 1984: 86-7). Whether or not Pythagoras had a golden thigh is, for instance, a historical question (EP 2: 80), one more difficult to answer than we are likely to suppose. However much Hamlet might be derived from, or based upon, historical figures, those figures as they appear in this drama have been transfigured by Shakespeare's literary imagination.

To return to a point broached earlier, Peirce goes so far as to insist, regarding anyone desirous to discover the truth, "there is, after all, nothing but the imagination that can ever supply him with an inkling of the truth" (CP 1.46). So, "after the passion to learn there is no quality so indispensable to the successful prosecution of science as imagination" (CP 1.47). But Peirce is quick to point out: "There are, no doubt, kinds of imagination of no value in science, mere artistic imagination, mere dreaming of opportunity for gain" (CP 1.48), that is, mere "practical" imagination. What distinguishes scientific imagination from other kinds is that it "dreams of explanation and laws" (CP 1.48). He might have included that scientific imagination also dreams of instituting procedures by which the most rudimentary facts might be discovered (e.g., carbon dating as a procedure by which to determine when life first appeared on Earth). Some sciences are descriptive rather than nomothetic or, at least, far more descriptive than nomothetic. Indeed, history, as a science, is one of them (see, e.g., CP 1.272). The discovery of facts and laws depends to a far greater extent than we commonly realize on the exercise of the imagination, though an imagination tempered and tutored by the exacting demands of experimental inquiry. That of facts alone greatly depends on this. For example, the historical imagination of the painstaking historian is nowhere more evident in asking what, immediately upon being posed, are "obvious" questions, yet they are the ones that for lack of imagination have not been taken up (e.g., what were the everyday lives of ordinary people during, say, the medieval epoch like?).

To whatever extent this might be the case, the realist insists upon an irreducible difference between that which is independent of our thinking and that which depends on our thinking. Put more simply, the advocate of realism refuses to erase entirely the distinction between the real and the fictive. However fuzzy the boundaries might be, in practice, in particular cases, they are, in principle, to be defended against the widely influential rhetoric of unbridled constructivists. An historical account based on the best available evidence is different from one grounded unduly in conjecture and speculation. 

It is also necessary to identify what might be called the character of that reality, ${ }^{17}$ for the historical past is manifestly different from the historical present, though both are undoubtedly real..$^{18}$ From Peirce's perspective, the historical present is marked by vagueness and generality to a far greater degree than the historical past. The actuality of hinc et nunc is fundamentally different from that of having been (or having occurred or taken place). The haecceity of the present is the paradigm of haecceity, whereas that of the past is rather paradoxical. How could the past, as past, be here and now? An adequate understanding of both the historical past and the historical present requires us to realize that the past is not simply past. More accurately, the historical past is not in all respects simply annihilated by the ceaseless self-annulment of the historical present. In annulling itself, the cutting edge of the present cuts off the present from the past, the now from the no longer. But there is more to this story than a tale of rupture, a drama of discontinuity. 19

The past is in some form there to be known, though this there turns out to be hard to specify. To some extent, the past as past, the past as that which no longer exists in the manner of the present, can be known. Like every other instance of reality, the reality of the past is that which exists independent of what you or I or any other finite individual happens to think about the past. This however calls for clarification. At the level of abstract definition, the reality of the past is identical in meaning to that of any other object of inquiry. At the level of pragmatic clarification, however, the linkages of this reality to thought, not its independence, need to be brought into focus. While the abstract definition seeks to clarify the meaning of reality by highlighting the contrast between the real and the fictive, the difference between reality and the vagaries of our thoughts regarding reality, pragmatic clarification foregrounds not only the link between reality and intelligibility but also the processes by which the possibilities of discovery and understanding are most effectively realized.

Before trying to show how these grades of clarity bear upon the meaning of history, however, we must first clarify what Esposito takes to be, in contrast to the objectivist stance, the constructivist approach to human history. The word history is of course ambiguous. It might designate what actually happened or the attempt to record or discover what actually happened. As Esposito puts it, it might mean "history as that which the historian studies and history as that which the historian produces from his study" (Esposito 1983: 156). It is however not simply a matter of emphasis. While the objectivist is stressing the importance of attending to what actually happened and the constructivist the necessity of acknowledging the extent to which even the most responsible historiographers are engaged in an imaginative reconstruction of a largely (if not entirely) elusive past (cf. Miller 1981: 186), the difference between the two is more than a difference in emphasis. To take an exemplar of objectivism, Leopold von Ranke was not only focused on discovering in detail what actually happened but also scornful of attempts by such thinkers as Hegel to interpret human history in terms of sweeping claims (e.g., the whole of this history is, at bottom, the story of the struggle for freedom). To take an exemplar of constructivism, R. G. Collingwood, a thinker who was in important respects quite close to Hegel, the task of the historian is not so much to discover as it is to re-enact the thoughts of the past. History is the drama of such re-enactment. The reality of the historical past is, for the objectivist, something to be discovered, in a manner closely akin to, if not identical with, the manner in which anything else is discovered 
(specifically, by the framing, testing, revising, and rejecting hypotheses). ${ }^{20}$ In contrast, the significance of the historical past is, for the constructivist, something to be constructed or created. What has actually happened derives its point and purpose from how it focuses the energies and enlarges the imagination of agents in the present. The historical past is made up not of dead facts but of enlivening forces. For the constructivist at least, history is not a meaningless sequence of "just one damn thing after another," but an intelligible series of intertwined developments. For the pragmatist, it is no less so.

A way out of this impasse can be glimpsed by tracing the implications of a claim made by J. W. Miller. ${ }^{21}$ What he wrote about history helps us to grasp the most salient features of what I am calling historical consciousness. He addressed these questions more explicitly and directly than Peirce tended to do, but his approach was deeply akin to Peirce's. Hence, I am here appealing to his formulations. "One may, and [indeed] one must," Miller asserts, "allege that the concerns that animated Plato were not brought to completion" (1981: 83) by him or any of his successors, including ourselves. Above all else, the crisis of the polis at the center of Plato's project, the ensemble of events to which his philosophy is a response, ${ }^{22}$ did happen long along in another place than that in which we now dwell. But, at the very least, the reverberations of this crisis can be heard and felt in the systematic failures of our political institutions. "We are," as Miller so poignantly notes, "the heirs not only of past wealth, but also of past debits" (Miller 1981: 188). Plato's "failure" to respond adequately to this crisis is not only his. It is also ours. Or, to take another example, the concerns that animated the pre-Socratics in their efforts to envision the world of their experience as a cosmos were far from brought to completion by their labor or genius. Despite the scientific revolutions intervening between their allegedly inaugural efforts and contemporary investigations, our efforts and theirs are continuous. Moreover, ours are no more likely to be brought to completion in the millennia after us than were theirs. If this is so, we are not making or re-enacting the thoughts of our predecessors but are renewing or simply prolonging their efforts to bring to fuller realization their unfinished projects, without necessarily any hope of bringing these to final closure or definitive completion. We consciously join some specific ancestors in some specific regard (e.g., Plato as a thinker whose project is bound up with the history of Athens, especially as symbolized in the execution of Socrates) because we discover, time and again, that we are fatefully enjoined to some inherited undertaking. Our current crisis is the unwitting prolongation of an unresolved issue bequeathed to us by historical figures from whom we can dissociate ourselves only by maiming our identity and vitiating our agency. We no more invented science, philosophy, or politics than the language we speak or the morals we enact, not least of all revealing ourselves to be inheritors, rather than creators, in our linguistic innovations or moral "transvaluations" (cf. MacIntyre 2006).

38 Accordingly, the historical past is, at once, continuous with the past (e.g., Plato's struggles to conceive the polis as a place in which justice might be effectively operative are in effect taken up anew by succeeding generations) and discontinuous with that past (no simple return is possible, since our time is in critical respects markedly different from earlier times). Neither continuity nor disruption can be the final word. Both historical knowledge and consciousness require a detailed, nuanced, and accurate understanding of the respects in which history exemplifies the dialectic of continuity and disruption.

The historical past is hence not so much given as won. We must work to achieve both knowledge and consciousness of it. This can be construed as a form of constructivism, but 
given Peirce's realism this is likely to be more misleading than accurate. In particular, the form of constructivism being advocated by Esposito and attributed by him, however circumspectly, to Peirce is one in which the historical past is decidedly not created out of whole cloth. It is, in addition, not sewn together from the merely disparate scraps from exquisitely designed garments long ago torn asunder. It is rather an historical past with a more or less determinate shape. ${ }^{23}$ It has such a shape, however, because it is the past claimed by those who have a determinate sense of their present identity (e.g., an understanding of themselves as participants in a specific field of scientific research or citizens of a specific nation).

But what is so characteristic of his thought in other contexts is also discernible in Peirce's writings on history and allied topics. He is anxious to do just to reality, in particular, the reality of history, lest we remove from under the feet of historians the ground on which they so reasonably claim to stand. In a perfectly straightforward sense, then, the craft of the historian is focused on what has taken place, even though we are never in a position to perceive historical events or even, in most instances, not in a position to call upon the living memory of direct witnesses who were at the time in the position to perceive them. But historical knowledge even in this narrow sense hardly exhausts our concern with history. Yet even in this narrow sense the thirdness and secondness, the intelligibility and actuality (or "objectivity"), of history are of focal concern. Allow me to make this point precisely in reference to Peirce. He self-consciously intervened in the history of logic for the purpose of re-orienting the science of logic, desiring to recast it as a normative theory of objective inquiry. The deliberate cultivation of historical consciousness made this possible, so much so that his self-conscious intervention in this ongoing history was inseparable from his historical consciousness of his specific locus in the actual history of the logical theory. Such historical consciousness is more than historical knowledge. Its cultivation points beyond objectivism to constructivism. Esposito suggests, "as soon as one raises the question of the priority of the disciplines among each other [e.g., as soon as one considers that, say, mathematics and phenomenology are prior to psychology and history], the transcendental perspective of historical consciousness enters the picture" (Esposito 1983: 161; emphasis added). ${ }^{24}$ In other words, we supposedly need to go beyond history in order to ground our knowledge of history (in a word, we need to go transcendental). For reasons far from clear, Esposito seems to hold that the conditions for the possibility of our experimentally acquired knowledge of history are transcendental rather than "merely" historical. So, "instead of looking upon history as an objective human past, 'the past' becomes a metaphysical category interpreted according to a particular category of modality called 'actuality' or 'existence"' (Esposito 1983: 161). As a result, "'history' becomes the name for the living theoretician's construction of human memories, signs, and inferences" (Esposito 1983: 161). Here I imagine Peirce resisting Esposito's insistence on historical consciousness requiring a transcendental perspective and, moreover, history being a construct in any sense opposed to realism.

41 But Esposito is certainly right in taking "the past" to be either a category or a phenomenon to which Peirce's categories was applicable. Regarding history, the memories, signs, and inferences to which he refers are unquestionably instances of Thirdness and, as such, are "not literally capable of existence or actuality." More cautiously put, they are not capable of being fully or exhaustively embodied in actuality. One of the most important implications of this constructivist stance toward human 
history is that the actuality of the irrevocable past is not allowed to eclipse the intelligibility of an ongoing history. To do justice to history, both the irrevocable actuality (the past as a fully determinate domain of fait accompli) and the alterable significance of the historical past need to be fully given their due.

The tension identified by Esposito is hardly a contradiction. Peirce might be characterized as both an objectivist and a constructivist, but it would be, in my judgment, better to identify him as a realist and a pragmatist (even better, as a pragmatic realist). And his own pragmatism enables us to see how fully these apparent rival stances complement rather than preclude one another. At the level of abstract definition, the past - better, the reality of the past - designates a rather paradoxical form of haecceity. At the level of pragmatic clarification, however, it points to an equally paradoxical feature of the past - its revisability (not merely the revisable character of our "knowledge" of the historical past, but also the alterable significance of the irrevocable past itself). One of the paradoxes of the past is that its having been and hence its being no longer are what it is and what will remain ever afterwards. The actuality of the past can no more be gainsaid than that of the present, though the actuality of fait accompli is not the same as that of what exists here and now (that which in the present crowds out a place for itself ( $C P$ 1.432)).

The principal task of the historical inquirer is to discover, on the basis of evidence, the actuality and reality of the past. This is as true of the intellectual historian as any other kind of historian. But this task relies as much as anything else, save the passion to ascertain the truth, on imagination ( $C P 1.46)$. It is not only rooted in historical imagination but also blossoms into various forms of this intellectual flora. The growth of a plant is partly the result of an ongoing interaction between the internal structure of the plant and the environing conditions, including light emanating from a star over ninety million miles away. So, too, is that of historical consciousness or imagination. ${ }^{25}$ It is truly the consequence of a dialogue, multifaceted and multileveled.

\section{Human History: The Ongoing Dialogue with an Irrevocable Yet Revisable Past}

The past addresses us in a language we barely understand, if we do indeed comprehend its modes of articulation at all. ${ }^{26}$ There are far too many cases where our most focused, sustained, and ingenious efforts have been frustrated to encourage unbridled confidence in our ability to divine even the most rudimentary facts about the historical past. But, then, there are too many instances in which we have been successful in our efforts to make sense out of the perceptible traces of the historical past to warrant wholesale skepticism regarding historical knowledge.

Let us however recall here what Peirce suggests in a passage having no explicit link to historical knowledge. "Some [signs] address themselves to us, so that we fully apprehend them [as signs]. But it is a paralyzed reason that does not acknowledge others that are not directly addressed to us, and that does not suppose still others of which we know nothing definitely" (NEM IV: 299). The traces of the past are among the most prominent of signs not addressed to us, ${ }^{27}$ but ones availing access to facets of what is no longer extant. It would indeed be a paralyzed reason that was unable to imagine the ubiquitous possibility of historical traces and, moreover, one that was unable to generate reasonable 
conjectures about at least the historical past in its roughest outlines (e.g., from the evidence available to us at the site of this dig, there appears to have been a cluster of dwellings adjacent to one another and, in addition, structures possibly serving functions other than shelter or dwelling, perhaps temples or, more cautiously, what would be in this culture the analogue of such a building).

The allegedly simple fact of there having been, at this site, such a village or assemblage of dwellings is itself noteworthy. Beyond this, however, there might be clues regarding the form of life made possible in part by this cluster of structures. Even the most rudimentary of historical facts are necessarily neither dead nor deadening (cf. Esposito 1983: 157-60; Esposito 1984: 141). They might be lively and enlivening. When they prove to be, historical "knowledge," even when it turns out to be erroneous, fosters historical consciousness, dramatic identification with almost always anonymous agents far removed from contemporary life. ${ }^{28}$

The paintings on the wall of a cave disclose to us those engaged in a form of life akin to our own, even if we have not yet been able to ascertain the significance of those paintings. ${ }^{29}$ Our encounter with them almost certainly enlivens our imagination and holds our interest, prompting us to ask, Who were the people who crafted these images? What were they, in terms of their self-understanding, ${ }^{30}$ doing when they were pictorially using pigments to capture these animals? Even the most remote ancestors are ancestors, even the most enigmatic utterances are utterances and, almost certainly, also enactments.

The exacting "price of a historical past is," as Miller notes, "a historical present" (Miller 1981: 179). The fixed present is however anything but an historical present. Where there is a fixed past, it is in the interest of a fixed present, so that one 'is' of a certain race or creed or nation, not that one could become so [or cease to be so], not that the past was also a becoming in its own time and place" (Miller 1981: 179-80). As the title of Octavio Paz's Nobel Lecture implies, we have to go in search of the present and, to a degree we could never have anticipated, this search drives us deeply and intimately into the historical past (the past as both that which itself became in its own time and place and that with which many of our simplest acts (e.g., our acts of speaking and gesturing) are inexorably bound up. ${ }^{31}$

The exacting price of an historical present is an historical past. We can no more have an historical present without an historical past than we can have an historical past without an historical present. Again, let us take Peirce as an example of this point. As a philosopher of science, Peirce felt compelled to make himself into a historian of science. Undoubtedly, he was inherently fascinated by history, but his painstaking engagement in the imaginative reconstruction of the historical drama in which his most noteworthy predecessors and contemporaries strove to carry forward the groundbreaking work of the ancient logicians was rooted in more than this fascination. It derived from his passionate involvement in this unfinished drama. That is, his present concern required the careful cultivation of his historical consciousness. But, then, the historical past, when candidly acknowledged as a fateful inheritance, demands a historical present. For example, the failure of our forebears to fulfill their tasks imposes upon us, here and now, the need to take up those tasks. For instance, the failure of Reconstruction after the Civil War in the United States is not simply that of those who were living in the decades after that horrific conflict. It defines the citizens of this country still. Speaking as an American, one must acknowledge that their failure is yet ours. So, a historical past demands a 
historical present no less than a historical present demands a historical past (as much as anything, the conscientious cultivation of historical consciousness). To go in search of the present ineluctably leads to the ruins of the past (Paz 1991). Such ruins are however part of the landscape of the present. To know where we presently stand, thus, requires us to see what constitutes the contours of this landscape, not least of all these ruins, but also the intricate designs they intimate and epochal energies they indicate.

\section{Conclusion: The Unfolding Drama of Historical Imagination}

50 "The nature of history," Erik Erikson predicted over fifty years ago, "is about to change." He was practically certain that: "It cannot continue to be the record of high accomplishments in dominant civilizations, and of their disappearance and replacement" (Erikson 2000: 224). ${ }^{32}$ The shared fate of human beings demands "new ethical alternatives" and, accordingly, a transfigured historical consciousness.

51 History has indeed changed in our times, though not exactly in the manner identified by Erikson. And it is bound to change just as profoundly time and again. There is no ahistoric matrix in which historical processes unfold (Esposito 1984). And history is not a process of evolution in the etymological sense. The contexts in which change occurs are themselves changing. They are through and through historical as is our understanding hence, our relationship - to these contexts. A philosophy of history must be nothing less than a philosophy of contexts (cf. Esposito 1984: 6), one in which the historical nature of complexly related contexts is illuminated in its most salient details. As it historically played out, the elevation of mathematics involved the denigration of history, despite the ingenious efforts of such early critics of the Cartesian framework as Vico (Fisch 1986: Ch. 11; and MacIntyre 2006). But, a century before Thomas Kuhn, Charles Peirce discerned the relevance of history for an understanding of science and, indeed, for all else.

"The stone the builders rejected has become the head of the corner" (Fisch 1986: 214; cf. MacIntyre 2006). ${ }^{33}$ And this has been accomplished in no small part because of the indefatigable and imaginative efforts of Peirce to give history its due. Only thus can science and more generally signs and symbols be given their due. The voluminous writings of this still elusively enigmatic genius are in effect nothing less than monumental testimony to this heuristic principle. They are indeed a dramatic instance of monumental history in the Nietzschean sense, above all, because we encounter there, in however compressed and thus elliptical a form, a compelling case for the historical past as both an irrevocable actuality and an inescapable inheritance of unfinished tasks (also broken promises and fateful evasions). The significance of the past is nearly as malleable as the actuality of the past is unalterable. Since we are first and foremost agents caught up in processes and practices for the most part transcending our consciousness and control, but ones in which our interventions and innovations are often far from inconsequential, our present is dramatic. A guiding sense of the historical past is an integral feature of deliberative rationality. Such rationality is deliberative by virtue of being dialogical (cf. Bernstein 1992: 52). Signs are "the only things with which a human being can, without derogation, consent to have any transaction" (CP 6.344). This includes the monuments, documents, and other traces of the past. 
53 Our dialogue with history can be a largely unsuspected farce in which we impose contemporary categories on past forms of human life. For it can be one in which we are not only unconsciously engaged but also one in which we obliviously commit the sin of anachronism! But it can also be a gentle comedy in which our limitations, errors, and shortcomings are revealed to us by our dramatic encounter with human beings whose irreducible otherness, hence whose unassimilable modes, prove time and again critical for assisting our self-understanding and self-overcoming. ${ }^{34}$ In brief, our dialogue with history is a process in which anachronism is hardly avoidable ${ }^{35}$ yet possibilities for selfunderstanding and self-transformation are readily available. In his dialogue with his past, however, Peirce strove to avoid anachronism (see, e.g., CP 7.181) and also to exploit these possibilities. In our dialogue with his writings, we are ineluctably drawn into his imaginative dialogue with the historical past. To read Peirce seriously is, indeed, to be caught up in the unfolding drama of human fallibility, ${ }^{36}$ rendered increasingly selfconscious, ${ }^{37}$ a drama in which the epoch-making power of experimental intelligence emerges as a central figure in the tragicomedy of our age. Hubris and the blindness resulting from it are unquestionably part of the story of our time, but so too are those revelatory yet comic episodes in which we realize just how foolish or stupid we have been, though without causing much, if any, harm. In being drawn into his thought in this manner, we are driven to place dramas of self-correction at the center of a life devoted to self-overcoming (see, e.g., Peirce 1966: 274; CN I: 188-9; see also Colapietro 1989: 95-7).

\section{BIBLIOGRAPHY}

AMBrosio Chiara, (2016), “The Historicity of Peirce's Classification of the Sciences," European Journal of Pragmatims and American Philosophy, 8, 2.

BARNES Julian, (2011), The Sense of an Ending, New York, Alfred A. Knopf.

BARZUN Jacques, (2001), From Dawn to Decadence, New York, Harper Collins.

BERNSTEIN Richard J., (1971), Praxis and Action: Contemporary Philosophies of Human Activity, Philadelphia, PA, University of Pennsylvania Press.

BERNSTEIN Richard J., (1992), The New Constellation: The Ethical-Political Horizons of Modernity/ Postmodernity, Cambridge, MA, MIT Press.

BOLER John, (1963), Charles Peirce and Scholastic Realism: A Study of Peirce's Relation to John Duns Scotus , Seattle, WA, University of Washington Press.

BRANDOM Robert, (2002), Tales of the Mighty Dead: Historical essays in the Metaphysics of Intentionality, Cambridge, MA, Harvard University Press.

BRUNSON Daniel, (2010), Pragmatism and the Past: C. S. Peirce on the Conduct of Memory and History, PhD. Dissertation, Pennsylvania State University, University Park, PA, USA.

BURBIDGe J. W., (1981), “Peirce on Historical Explanation,” in L. W. Sumner et al. (eds.), Pragmatism and Purpose: Essays Presented to Thomas A. Goudge, Toronto, University of Toronto Press, 15-27. 
COHEN Morris R., (1947), The Meaning of Human History, La Salle, IL, Open Court Publishing Co. COLAPIETRO Vincent, (1989), Peirce's Approach the Self, Albany, NY, SUNY Press. COLAPIETRO Vincent, (1999/2000), “Translating Signs Otherwise," Athanor, X, 2, edited by Susan Petrilli, 102-23.

COLAPIETRO Vincent, (2003), The Fateful Shapes of Human Freedom: John William Miller and the Crises of Modernity, Nashville, TN, Vanderbilt University Press.

COLAPIETRO Vincent, (2004), "Portrait of a Historicist: An Alternative Reading of Peircean Semeiotic," Semiotiche, 2, 4, 49-68.

COLAPIETRO Vincent, (2013), "Processes of Imaging and Imagining: Toward a Pragmatic Clarification of the Image," Recherches sémiotiques* Semiotic Inquiry [RS*SI], 33, numbers, 1, 2, \& 3, 95-114.

COLAPIETRo Vincent, (2016), “The Dissenting Voice of Charles Peirce," The Varieties of Transcendence , New York, Fordham University Press, 185-218.

CoLLINGWOod R. G., (1994), The Idea of History [Revised Edition], Oxford, Oxford University Press DEWEY John, (1983 [1922]), Human Nature and Conduct, The Middle Works of John Dewey, volume 14, edited by Jo Ann Boydston, Carbondale, IL, SIU Press. Cited as MW 14.

DEWEY John, (1984 [1931]), "Philosophy and Civilization," The Later Works of John Dewey, volume 3, edited by Jo Ann Boydston, Carbondale, IL, SIU Press, 3-10.

DEWEY John, (1988 [1940]), “Time and Individuality,” The Later Works of John Dewey, vol. 14, edited by Jo Ann Boydston, Carbondale, IL, SIU Press, 98-114. Cited as LW 14.

EISELE Carolyn, (1979), Studies in the Scientific and Mathematical Philosophy of Charles S. Peirce, edited by Richard M. Martin, The Hague, Mouton Publishers.

ERIKSON Erik, (2000), The Erik Erikson Reader, edited by Robert Coles, New York, Norton \& Co.

ESPOSITo Joseph L., (1979), “The Development of Peirce's Categories,” Transactions of the Charles S. Peirce Society, 51, 1, 51-60.

ESPOSITO Joseph L., (1983), "Peirce and the Philosophy of History," Transactions of the Charles S. Peirce Society, 19, 2, 55-65.

ESPOSITO Joseph L., (1984), The Transcendence of History: Essays on the Evolution of Historical Consciousness, Athens, OH, Ohio University Press.

FISCH Max H., (1970 [1959]), “The Philosophy of History: A Dialogue," Studies in Philosophy and in the History of Science: Essays in Honor of Max Fisch, edited by Richard Tursman (Lawrence, KS, Coronado Press), 193-206. Originally publish in Philosophy (Keio University, Tokyo), 36, 149-70.

FISCH Max H., (1986), Peirce, Semeiotic, and Pragmatism, edited by Kenneth Laine Ketner \& Christian J. W. Kloesel, Bloomington, IN, Indiana University Press.

GAllie W. B., (1952), Peirce and Pragmatism, Harmondsworth, Middlesex, Penguin Books.

GALLIE W. B., (1968), Philosophy and the Historical Understanding, New York, Schocken Books. HELM Bertrand P., (1985), Time and Reality in American Philosophy, Amherst, MA, University of Massachusetts Press.

JAMES William, (1978), Pragmatism, Cambridge, MA, Harvard University Press. 
KETNER Kenneth Laine, (1973), An Emendation, Lubbock, TX, Texas Tech University Press.

LATOUR Bruno, (2013), Inquiry into Modes of Existence: An Anthropology of the Moderns, Cambridge, MA, Harvard University Press.

MACINTYRE Alasdair, (2006 [1977]), "Epistemological Crises, Historical Narrative, and the Philosophy of Science," in The Tasks of Philosophy, Cambridge, Cambridge University Press, 3-23. Originally published in The Monist (1977).

MARGOLIS Joseph, (1993), The Flux of History and the Flux of Science, Berkeley, CA, University of California Press.

MARSHALL David L., (2013), “The Implications of Robert Brandom's Inferentialism for Intellectual History," History and Theory 52 (February), 1-31.

MARK Karl, (1983), The Marx-Engels Reader, ed. Robert C. Tucker, New York, W.W. Norton \& Co.

MILLER John William, (1981), The Philosophy of History, New York, Norton \& Co.

MILLER John William, (1983), In Defense of the Psychological, New York, Norton \& Co.

MILLER Willard M., (1971), "Peirce on the Use of History," Transactions of the Charles S. Peirce Society, 7, 2, 105-26.

MILLER Willard M., (1972), "Further Thoughts on Peirce's Use of History," Transactions of the Charles S. Peirce Society, 8, 2, 115-22.

MILLER Willard M., (1978), "Peirce on Pragmatism and History," Transactions of the Charles S. Peirce Society, 14, 1, 42-52.

NIETZSCHE Friedrich, (1957), The Uses and Abuses of History, translated by Adrian Collins, New York, Macmillan.

PAZ Octavio, (1991), In Search of the Present [Nobel Lecture], Boston, Mariner Books.

PEIRCE C. S., (1931-58), The Collected Papers of Charles Sanders Peirce, volumes 1-6, edited by Charles Hartshorne and Paul Weiss, volumes 7 and 8, edited by Arthur W. Burks. Cambridge, MA, Belknap Press of Harvard University Press. Cited as CP (volume and paragraph \#, e.g., "CP 5.555" refers to paragraph 555 in volume 5 of the Collected Papers).

PEIRCE C. S., (1966), Selected Writings, ed. by Philip P. Wiener, New York, Dover.

PEIRCE C. S., (1982), The Writings of Charles S. Peirce: A Chronological Edition, volume 1, edited by the Peirce Edition Project, Bloomington, IN, Indiana University Press. Cited as $W 1$.

PEIRCE C. S., (1992), Essential Peirce, volume 1, edited by Nathan Houser and Christian Kloesel, Bloomington, IN, Indiana University Press. Cited as EP 1.

PEIRCE C. S., (1998), Essential Peirce, volume 2, edited by Peirce Edition Project, Bloomington, IN, Indiana University Press. Cited as EP 2.

PUTNAm Hilary, (1981), Reason, Truth and History, Cambridge, Cambridge University Press.

RANDALl Jr. John Herman, (1973), Plato: Dramatist of he Life of Reason, New York, Columbia University Press.

RANSDELl Joseph, (2000), "Peirce and the Socratic Tradition," Transactions of the Charles S. Peirce Society, 36, 3, 341-56.

RUSSELL Bertrand, (1921), The Analysis of Mind, London, George Allen \& Unwin, Ltd. 
SHORT T. L., (2007), Peirce's Theory of Signs, Cambridge, Cambridge University Press.

SMiтH John E., (1969), “Time, Times, and the 'Right Time'," The Monist, 53, 1, 1-13.

SMITH John E., (1986), “Time and Qualitative Time,” The Review of Metaphysics, 60, 1, 3-16.

SMITH Justin E. H., (2016), “No, He’s Not Hitler. And Yet ...,” 'SundayReview,' New York Times (June 5), 9.

TRILLING Lionel, (2008 [1950]), The Liberal Imagination, New York, New York Review Books.

VioLA Tullio, (2015), Philosophy and History: The Legacy of Peirce's Realism, PhD Dissertation,

Humboldt University, Berlin, Germany.

VON RANKE Leopold, (1973), The Theory and Practice of History, Indianapolis, IN, Bobbs-Merrill, Co.

WEISS Paul, (1962), History: Written and Lived, Carbondale, IL, SIU Press.

WOODBRIDGE Frederick, (1916), The Purpose of History, New York, Columbia University Press.

\section{NOTES}

1. Of course, Fisch is here invoking a metaphor found in Christian and indeed Hebrew scripture (see, e.g., Psalms, 113, 118; Matthew 21, 41; and Mark 12, 10). My reason for attributing this metaphor to him is, in this context, that he uses the image to suggest history, that which has been thrown away by Descartes and countless other philosophers, provides Peirce with nothing less than the corner stone of a philosophical edifice built for inhabitants of our historical time. He does so, no doubt, with historical consciousness, as do I. But there is reason to make this explicit. The image is scriptural, the use to which Fisch puts it however is the one most directly relevant to this essay.

2. Significant steps toward such a clarification have already been taken by Willard Miller, Philip Wiener, Joseph Esposito, Tullio Viola, Chiara Ambrosio, Daniel Brunson, and others. In gratitude for their endeavors, I was disposed to use as my subtitle "Further Steps Toward a Pragmatic Clarification of Historical Consciousness"! This however would have made a title already too long and cumbersome even more so. But I am acutely conscious not only of the efforts of others but also my indebtedness to their work and insights. This essay is indeed an enactment of what it thematizes, a self-conscious endeavor to take up and carry forward a task already underway.

3. Especially in its ontological deployment, Peirce's concept of secondness was designed to capture what Scotus intended by haecceity (Boler 1963: 122, 164; cf. Bernstein 1971, 180-2). Secondness signifies "not mere twoness [or duality] but active oppugnancy is in it" (CP 8.291). It is that which is insistently and aggressively here and now - that which "blindly forces a place for itself in the universe, or willfully crowds its way in" (CP 1.459). For this reason, Peirce discerns at least an affinity between his understanding of secondness and the Scotistic recognition of haecceity.

4. Reading Peirce on the topic of history and indeed much else, I have learned much from those who were already prominent when I took up the study of Peirce - in particular, Carolyn Eisele, Max Fisch, Kenneth Ketner, Joseph Ransdell, T. L. Short, Lucia Santaella, Joseph Esposito - but I have learned no less from those younger than me (most notably, David Agler, Chiara Ambrosio, Daniel Brunson, Masato Ishida, and Tullio Viola).

5. In "Philosophy and Civilization" John Dewey writes: "Significant history is lived in the imagination of man, and philosophy is a further excursion into its own prior achievements" ( $L W$ 3: 5). This clearly implies not only that philosophy is an engagement with history but also that it is an adventure of the imagination. Elsewhere he astutely observes: "From the human standpoint 
our study of history is still all too primitive. It is possible to study a multitude of histories, and yet permit history, the record of the transitions and transformations of human activities, to escape us" (MW 14: 78-9).

6. Science was, for Peirce, "a mode of life whose single animating purpose is to find out the real truth, which pursues this purpose by a well-considered method, founded on thorough acquaintance with such scientific results already ascertained by others as may be available, and which seeks cooperation in the hope that the truth may be found out, if not by any of the actual inquirers [now engaged in its pursuit], yet ultimately by those who come after them and who shall make use of their results" (CP 7.54, emphasis added).

7. His self-understanding conjoined an unabashed commitment to traditional Christianity with an acute awareness of the revolutionary character of scientific inquiry. And this selfunderstanding is expressly dramatic: "A man is capable of having assigned to him a rôle in the drama of creation, and so far as he loses himself in that - not matter how humble it may be rôle, so far he identifies himself with its Author" (CP 7.572; Colapietro 2016). Peirce took himself to have been assigned the role of scientist. As a result, inquiry was for him a form of worship and, in turn, worship a practice in which the growth of understanding, above all else, selfunderstanding, was critical.

8. "Peirce was," Joseph Ransdell properly notes, "a radical thinker, attempting to re-think and re-establish logic at the most fundamental level, and it is appropriate [for us] to go back to the beginnings of logic in the West to understand what this means" (2000: 342). This is so because Peirce felt it was necessary for him to go back at least this far for the sake of executing this task.

9. The dispute between the realists and nominalists was, for Peirce, at bottom one regarding the nature and indeed the possibility of community, hence, one regarding continuity (in particular, the degree and forms of continuity between, or among, selves distant from one another, be it historical or some other kind of distance).

10. Fancy and phantasy were often used in the nineteenth century as synonyms for imagination. "Fancifully" hence might only refer to the exercise of imagination or, rather misleadingly to contemporary ears, "fancy." While Descartes drew a sharp distinction between intellect and imagination, Peirce returned to the scholastic position (human intelligence is rooted in and depends on our imaginative capacities). The poet Alfred Tennyson wrote, "maybe wildest dreams/Are but the needful preludes of the truth," to which Peirce responds: "I doubt the word maybe. Wildest dreams [or fancies] are the necessary first steps toward scientific investigation" (Peirce 1966: 233).

11. Whatever perspective from which "history needs to be written [or simply imagined] if it is to escape subjectivity, it seems that it, too, is, as J. W. Miller notes, a historical resultant. Thus the one necessary point of view from which history is to be written [at present] is self the outcome of history" (Miller 1981: 188). And, for the person engaged in this task, this must be a selfconsciously historical perspective. "The present is no Olympian height from which all history is to be judged as from some timeless perspective" (Miller 1981: 188). Rather this present is, to repeat, historical through and through.

12. Of course, one cannot conduct experiments in history in the same manner as one can in, say, physics or chemistry.

13. "Action is," Peirce suggests," second, but conduct is third" (CP 1.337). Action as that which takes place here and now is an instance of secondness, and hence needs to be clearly distinguished from that which is bound up with generality (be in the generality of a purpose or that of a habit or, of course, both, as is almost always the case). To avoid confusion, "action" expressive or indicative of generality might be designated as conduct, manifestly an instance of thirdness.

14. "Successful research," Peirce suggests, "is conversation with nature; the macrocosmic reason, the equally occult microscopic law, must act together or alternately, till the mind is in tune with 
nature" ( $C P$ 6.568). What such research facilitates is a finer and fuller attunement between the habits of rational agents and the dispositions of the countless objects encountered in the course of experience. "An experiment, says Stöckhardt, in his excellent School of Chemistry, is a question put to nature. Like any interrogatory, it is based on a supposition. If that supposition be correct, a certain sensible result is to be expected under certain circumstances which can be created, or at any rate are to be met with. The question is, Will this be the result? If Nature replies 'No!' the experimenter has gained an important piece of knowledge. If Nature says 'Yes,' the experimenter's ideas remain just as they were, only somewhat more deeply engrained" ( $C P$ 5.168). "Experiment, after all, is an uncommunicative informant. It never expiates: it only answers 'yes' or 'no'; or rather it usually snaps out 'No!' or, at best only utters an inarticulate grunt for the negation of its "no"' (CP 5.428). Even so, there is much to be learned from these inarticulate grunts!

15. "[O]f the myriad forms into which a proposition may be translated," Peirce asks, "what is that one which is to be called its very meaning? It is, according to the pragmaticist, that form in which the proposition becomes applicable to human conduct, not in these or those special circumstances, nor when one entertains this or that special design, but form which is most directly applicable to self-control under every situation, and to every purpose. This is why he locates the meaning in future time; for future conduct is the only conduct that is subject to selfcontrol" (CP 5.427; see Colapietro 1999/2000).

16. John William Miller suggests, "where nothing is cherished nothing is found" (Miller 1981: 111). What he immediately goes on to say is even more pertinent to our purpose: "Now this seems to be a matter of some weight, but likely to be passed over, or denied, in our factually oriented idiom. For to cherish requires emotion and will. If there are to be memorials [or monuments] they have to be treated as memorials. There are no monuments of the past as matters of fact. [...] There are no monuments in terms of the traditional epistemology of passivity [that in which objects are given rather than constructed]. A past has to be actively treasured if it is to be perceived as a past" (Miller 1981: 111, emphasis added).

17. This distinction is central to Esposito's argument in "Peirce and the Philosophy of History" (Esposito 1983). Insisting upon the reality of the past, as the objectivist or commonsensist does, is understandable and even valid, but the task of clarifying the meaning of this reality cannot be skirted. This is correct, but it hardly entangles Peirce in the difficulties that Esposito alleges.

18. Of course, one might object that it is possible to doubt the reality of the past. "There is," Bertrand Russell proposed, "no logical impossibility in the hypothesis that the world sprang into existence five minutes ago, exactly as it then was, with a population that 'remembered' a wholly unreal past. There is no logically necessary connection between events at different times; therefore, nothing that is happening now or will happen in the future can disprove the hypothesis that the world began five minutes ago. [...] I am not here suggesting that the nonexistence of the past should be entertained as a serious hypothesis. Like all skeptical hypotheses, it is logically tenable but uninteresting" (Russell 1921: 159-60). Peirce would however take such a fanciful doubt about the existence of the past to be merely a "paper" doubt. The fact that we can put words done on paper in the form of an interrogatory does not mean that we are genuinely in doubt.

19. "Ordinarily change is measured with reference to the permanent and is explained in terms of the permanent. Thus a change in weather gets explained by reference to the unchanging laws of air masses. [...] But historical change involves one in the paradox of attempting to understand the discontinuous. It seems plain that if there were no discontinuous change there could be no historical knowledge as an independent sort of knowledge" (Miller: 1981: 187-8). It however seems equally plain that absolute rupture renders historical impossible: bridges between the past and present must be construct in order for the past, at least in a determinate, intelligible form, to reached by us who are, at once, bound to the historical present and, principally by virtue of the 
critical resources provided by historical consciousness, possess a limited capacity to transcend the all too narrow bounds of an insular present (cf. Esposito 1984: Ch. 5).

20. "A discussion of history does well," J. W. Miller observes, "to avoid an alienation from natural science so abrupt that in the end the two interests confront each another as incommunicable. At the same time one can hardly avoid differences that at first do seem alienating. Science eventuates in formulae. [...] History, in contrast, needs acts, agents, dates, places, desires, and passions. In order to study these, it employs a peculiar sort of material - namely, documents and monuments" (Miller 1981: 107). History as a distinctive form of experimental inquiry is, at least in general terms, no different from other forms of such inquiry. But, for the most part, history as the imaginative reconstruction of the historical past undertaken for the sake of deepening our consciousness of our own historicity cannot be assimilated too closely to such disciplines as physics, chemistry, or even biology.

21. Miller's work deserves to be far better known than it is. While he was critical of pragmatism, especially James's version of this doctrine, he was, partly through his intellectual kinship with Royce's absolute pragmatism, much closer to Peirce than he realized.

22. Here, too, Miller's counsel is instructive. The "action with which one deals in history is always a reaction" (Miller 1981: 191) or, since the term is less likely to have mechanistic implications, a response. "We reacted," Miller notes, "to Pearl Harbor. Perhaps no one knows all the factors of temper in that reaction [or response]. Nor could one say in advance of the reaction" just what the reaction or response would be. One [indeed] never knows apart from what is done at a time and place" (ibid.; emphasis added). Antecedent conditions do not determine these responses, however much they might color of influence how rational agents respond to historical events. No reductionism is intended here. To see Plato's project as a response to the crises of the polis does not imply that it is nothing but such a response. In turn, to see Peirce's philosophy as a response to the crises generated by Darwin's theory of evolution does not imply that it is nothing but such a response. Even so, we understand both thinkers only when we take with the utmost seriousness the profound crises by which their philosophical projects were, in part, generated.

23. This implies a distinction between the merely chronological and the truly historical past. "The chronological past," J. W. Miller contends, "has no shape. It is all the vents common to all points of view. The historical past has shape. It is not a common past. It is peculiar to each society, for each society has its own past as surely as it has its own present" (Miller 1981: 165). He adds: "Only the particular present [i.e., the present of us, here and now] has a historical past. Therefore, the historical past will be as particular as its present extension [or prolongation]" (ibid.). To make this concrete, consider the intergenerational community of experimental scientists with which Peirce so deeply identified (see, e.g., CP 8.101). This is in a sense a society, a more or less integrated assemblage of distinct individuals. Contemporary members of this specific society do not claim just anyone who lived before them (i.e., who chronologically antedates them) as their ancestors. They would almost certainly see Thales, Ptolemy, Galileo, Copernicus, Newton, and countless specific others as their scientific forerunners.

24. This does not necessarily mean that we transcend history in its entirety or in every sense, only history taken to be a determinate field of purely objective knowledge.

25. The life of experimental intelligence is as much as anything else an adventure of the human imagination. So, too, the evolution of historical consciousness (or imagination) is such an adventure. There are no doubt distinct senses of this protean term. Peirce goes so far as to suggest, “imagination' is an ocean-broad term, almost meaningless, so many and so diverse are its species" (Peirce 1966: 255). But the several senses at play in this paper - scientific, historical, and by implication moral - are distinct, though not incompatible. 
26. "The past cannot address one," John William Miller suggests, "in one's own language. One must learn the language of the past. It is not accommodating or kind, and can't be ordered to make itself clear to one" (Miller 1981: 187; cf. Colapietro 2003).

27. Even here, it is necessary to be cautious. Are we necessarily in a position to know that a monument constructed millennia ago was not addressed to unknown future generations?

28. "History is not," Miller insists, “'about' a past; it is [in the present] a disclosure and vehicle of the past. Except as a career and continuum there is no past to write 'about.' And if a career, then the present has joined and embraced the past" (Miller 1981: 178-9). "The very word 'politics' is Greek, not biblical. Their career is also ours" (Miller 1981: 135). However remote and alien we are from the ancient Athenians, our political life is in some manner and measure continuous with theirs. Such dramatic identification is at the bottom of all historical consciousness. Miller goes so far as to suggest, "what seems analogical is actually a search for identity. We ask, "Who were the [ancient] Romans?' We [simply in posing this question seriously] join them in self-definition, not in a technical problem. By knowing themselves better we know ourselves better. We profit not from a technical skill or failure, but from the common political purpose that is self-disclosing" (ibid., emphases added). With regard to history in this sense, "one is here dealing not with analogy, but in a career. We are together in a career, not as technicians." In the sense most relevant here, history is, in other words, a drama in which we are implicated and, as such, one in which the dramatis personae includes far more than contemporary actors.

29. "In the caves of the Pyrenees there are drawings of a herd of deer. A friend of mine, a lawyer, who saw them, gave me a quiet but stirring account of his visit. What was it that he saw? A pretty picture? That would not have prompted his words or his manner. Nor was he commenting on the degree of intelligence of Neanderthal man. It was, rather, that in those caves something was revealed. Here was a voice, an utterance, an announcement, not of any matter of fact, but the presence of men and objects. These drawings were a voice. "Out of the silence a voice, out of the darkness a light. In the story of chaos from which the world emerged it was the generation of particulars - earth, sky, vegetation - that brought content and form. I think that my friend felt he was a spectator of the creation. On what other basis could one find anything [so] awesome in those drawings? The maker, the poet, saw himself in telling what he saw. He is not represented there, but presented" (Miller 1981: 103-4).

30. In asking this question, we need not project onto them reflexive or explicit forms of selfunderstanding, only a vague sense of the import or function of their own characteristic endeavors.

31. Our relationship to our language implicates us as inheritors. "We do not come upon a past," Miller insists, "as upon something new, extraneous, or merely additional. To inherit one's mother tongue is to have spoken and to have heard, to have been addressed and to have attended to others. Something of the past has [always] already become part of one's activity. No one begins a lively acquaintance with objects or persons by studying history. One learns first to conduct oneself in ways that only later on disclose their historical implications" (Miller 1981: 179, emphasis added).

32. In The Sense of an Ending by Julian Barnes, the protagonist muses, "History isn't the lies of the victors. I know that now. It's more the memories of the survivors, most of whom are neither victorious nor defeated." This implies that history has never been simply "the record of the high accomplishments in dominant civilizations" (2011: 61).

33. As already noted, Fisch is here invoking a metaphor found in Christian and Hebrew scripture (see, e.g., Psalms, 113, 118; Matthew 21, 41; and Mark 12, 10). But it is his use of this metaphor that is most relevant to this essay, so citing his text seems only apposite.

34. 'Unlike his contemporary, Karl Marx, who sought to explain 'history in general' using a materialistic model that allowed only the most elementary recognition between effects and their conditions [hence between the ideological superstructure and the economic foundation], Peirce's 
model," Esposito suggests, "described history as a vast dialogue of significations and reflections, continually shedding contingencies and growing hyperbolically in the direction of greater concrete reasonableness" (Marx 1983: 65).

35. "The besetting sin of history is," Miller astutely observes, "anachronism, the description of any past in the terms of an abstract present. History writing that is not the imaginative reconstruction of the past on its own terms, indeed the very discovery of such terms, leaves the past as a mystery or else reduces it to the ahistoricity of scientific nature, to psychological atomism, or theological incomprehension" (Miller 1981: 186-7).

36. "It is truth well worthy of rumination," Peirce insists, "that all the intellectual development of man rests upon the circumstance that all our action is subject to error. Errare est humanum is of all commonplaces the most familiar" ( $C P$ 6.86; cf. $W 1$ : 5 ). But it might be as profound as it is familiar.

37. Picking up the thread from the previous note, the most important truth about human intelligence is that virtually all of our knowledge is the result of having made mistakes or, more precisely, flows from the exercise of our ability to proceed erroneously. The capacity to make mistakes is no mean or ignoble ability. The Peircean doctrine of thoroughgoing fallibilism is itself the dramatic outcome of a historical development, the uncompromising acceptable of our ineradicable fallibility conjoined to an equally robust faith in our ability to discover novel truths (see, e.g., CP 1.14). Abandoning the quest for apodictic certainty does not entail losing faith in the possibility of pragmatic certainty or confidence. But it does require us to acknowledge that approximation is the very fabric out of which our philosophy not only has been woven but also must always be woven (CP 1.404).

\section{AUTHOR}

\section{VINCENT COLAPIETRO}

Pennsylvania State University

vxc5[at]psu.edu 